\title{
Job satisfaction of nurses working in hospital units of northern Portugal
}

Satisfação profissional dos enfermeiros em unidades hospitalares do norte de Portugal Satisfacción profesional de los enfermeros en unidades hospitalarias del norte de Portugal

Carina Alexandra Salvador Ferreira*; Roberto Fernandez Fernandez**; Eugénia Maria Garcia Jorge Anes***

\begin{abstract}
Background: Nurses' job satisfaction should be measured because it plays a key role in the quality of healthcare delivery.

Objectives: To assess nurses' level of job satisfaction.

Methodology: A descriptive, analytical, exploratory, and quantitative study was conducted to assess nurses' job satisfaction using the Escala de Avaliação da Satisfação no Trabalho para Enfermeiros (Work Satisfaction Evaluation Scale for Nurses).

Results: Sample $(n=124)$, mostly female $(82.3 \%)$, with a mean age of 42 years. Nurses showed higher satisfaction levels in their relationship with the head nurse, the team, and the working context. Satisfaction is correlated with age, academic degree, hospital unit, length of service, ward, and remuneration.

Conclusion: Younger nurses, nurses with a lower academic degree, nurses with less than 10 years of service, and nurses with lower remuneration are more professionally satisfied. Job satisfaction levels are different across hospitals and wards. Job satisfaction should be systematically assessed and its determinants should be identified.
\end{abstract}

Keywords: job satisfaction; nurses; nursing

\section{Resumo}

Enquadramento: A satisfação profissional dos enfermeiros tem um papel central na qualidade dos cuidados prestados, pelo que se torna indispensável a sua mensuraçáo. Objetivos: Avaliar a satisfação profissional dos enfermeiros.

Metodologia: Estudo descritivo, analítico, exploratório do tipo quantitativo. Avaliamos a satisfação profissional dos enfermeiros através da Escala de Avaliação da Satisfação no Trabalho para Enfermeiros (EAST - Enf).

Resultados: Amostra $(n=124)$ predominantemente feminina $(82,3 \%)$, com média de idade a rondar os 42 anos. Os enfermeiros apresentam níveis de satisfação superiores no relacionamento com o chefe, com a equipa e com o contexto de trabalho. A satisfação relaciona-se com a idade, grau académico, unidade hospitalar, tempo de serviço, serviço e remuneração.

Conclusáo: Os enfermeiros mais satisfeitos profissionalmente são os mais jovens, com menor grau académico, com tempo de serviço inferior a 10 anos e com remuneração mais baixa. O nível de satisfação difere em cada unidade hospitalar e serviço. É importante efetuar a avaliação da satisfação profissional de forma sistemática, identificando os seus determinantes.

Palavras-chave: satisfação no emprego; enfermeiras e enfermeiros; enfermagem

*MSc., RN, Northeast Local Health Unit, 5370-429, Mirandela, Portugal [carinaferreira@ live.com.pt]. Contribution to the article: research design, data collection, statistical treatment, and article writing.

Address for correspondence: Rua Maria Perpétua Fins Tavares, nº48 r/chão, 5370-429, Mirandela, Portugal.

**Ph.D., Professor of Labor and Social Security Law, Department of Private and Corporate Law, University of León, 24071, León, Spain [rferf@unileon.es].Contribution to the article: research design and final revision.

***Ph.D., Adjunct Professor, School of Health, Polytechnic Institute of Bragança, 5300-146, Bragança, Portugal [eugenia@ipb.pt].Contribution to the article: research design, statistical treatment, discussion, and final revision.

\section{Resumen}

Marco contextual: La satisfacción profesional de los enfermeros tiene un papel central en la calidad de los cuidados prestados, por lo que es indispensable medirla. Objetivos: Evaluar la satisfacción profesional de los enfermeros.

Metodología: Estudio descriptivo, analítico, exploratorio de tipo cuantitativo. Se evaluó la satisfacción profesional de los enfermeros a través de la Escala de Evaluación de la Satisfacción en el Trabajo para Enfermeros (EAST - Enf).

Resultados: Muestra $(n=124)$ predominantemente femenina $(82,3 \%)$, con una media de edad que ronda los 42 años. Los enfermeros presentan niveles de satisfacción superiores en la relación con el jefe, con el equipo y con el contexto de trabajo. La satisfacción se relaciona con la edad, el grado académico, la unidad hospitalaria, el tiempo de servicio, el servicio y la remuneración.

Conclusión: Los enfermeros más satisfechos profesionalmente son los más jóvenes, con menor grado académico, con un tiempo de servicio inferior a 10 años y con una remuneración más baja. El nivel de satisfacción difiere en cada unidad hospitalaria y servicio. Es importante realizar la evaluación de la satisfacción profesional de forma sistemática e identificar sus determinantes.

Palabras clave: satisfacción en el trabajo; enfermeros; enfermería

Received for publication: 24.05 .17 Accepted for publication: 06.09.17

Série IV - n. ${ }^{\circ} 15$ - OUT./NOV./DEZ. 2017 


\section{Introduction}

Over the last decade, several theoretical and empirical studies have focused on job satisfaction, which is considered as "an essential condition to improve organizational functioning" (Dinis \& Fronteira, 2015, p. 19). The concept of job satisfaction is of paramount importance because it is directly or indirectly associated with personal achievement and, consequently, with corporate productivity. Hence, "it is important to assess not only the clients' needs, but also the workers' level of satisfaction and participation, making them feel satisfied in the development of their activities" (João, Alves, Silva, Diogo, \& Ferreira, 2017, p. 118).

Job satisfaction is a construct that seeks to respond to an emotional state or an attitude towards work and workplace experiences. "It is an important indicator of organizational climate and a crucial aspect in the assessment of the quality of organizations" (João et al., 2017, p. 117).

It can be seen as an important tool for human resource management, contributing to improve both the worker's and the organization's performance, which impacts the quality of professional life (Cañón Buitrago, \& Galeano Martínez, 2011).

Nurses' job satisfaction has become highly relevant in this economically troubled era. Due to the economic crisis, nurses have been facing several professional changes/limitations for the past 10 years, namely the freeze on automatic career progression and remuneration positioning. In addition, the current professional career does not distinguish between levels of training, which creates inequalities among nurses.

This situation is further aggravated by the population's aging and level of poverty, particularly in deserted interior regions.

In view of the above, the following questions are necessary and relevant: What is the level of job satisfaction of nurses working in hospitals of the Northeast Local Health Unit (ULSNE, Unidade Local de Saúde do Nordeste) in Portugal?

Therefore, this study aimed to assess the job satisfaction of nurses working in hospitals of the ULSNE in Portugal, as well as to identify its sociodemographic and professional determinants.

\section{Background}

According to the Basic Law on Health Care, health professionals' job satisfaction is one of the four criteria for periodic assessment of the National Health Service, along with users' satisfaction, quality of care, and cost-effective use of resources (Lei n. ${ }^{\circ}$ 27/2002, de 8 de novembro).

Several agencies have been discussing the topic of job satisfaction assessment, namely the Portuguese Order of Nurses whose research priority is the development of "studies about innovative strategies for management/leadership and work organization that promote and facilitate the quality of care in professional settings" (Ordem dos Enfermeiros [OE], 2006, p. 4).

The International Council of Nurses issued an opinion on the priority areas of nursing research and highlighted the need for health organizations to encourage research on nurses' job satisfaction (Conselho Internacional de Enfermeiros, 2007).

In addition, the World Health Organization recommends the assessment of the quality of life of the following groups: "chronic patients, patients' relatives and support carers, people in extreme situations, people with communication difficulties, and children" (Frade, 2010, p. 9). Nursing professionals may be considered as support persons to these groups, and the work-related physical, emotional, and mental specificities may compromise their quality of life.

According to Martinho (2015, p. 26), job satisfaction is "a very complex phenomenon, a concept related to an emotional state or an attitude towards work and the experiences in a given professional setting".

The assessment of nurses' job satisfaction is based on multiple dimensions "that influence their development: on the one hand, the factors intrinsic to the individual and, on the other, the influence of the organization and the current social and political context" (Valente, 2013, p. 73).

Simultaneously, the strategic axis for quali- 
ty in health of the National Health Plan for 2012-2016 (Direção-Geral da Saúde, 2013, p. 16), reads that institutions should "establish quality policies at the institutional level to ensure the quality of care and the safety of patients/users and professionals ... and monitor citizens and professionals' satisfaction". Martinho (2015) analyzed the association between nurses' job satisfaction and the variables of gender, marital status, professional experience, type of care provided, type of schedule, employment contract, and workplace. The author found higher levels of job satisfaction among female nurses, nurses who were married, had less professional experience, provided specialized care, had fixed work schedules, were permanent staff, and worked in the private sector.

Moura, Brás, Anes, and Ferreira (2016) also analyzed the influence of sociodemographic and professional variables on job satisfaction and found higher levels of satisfaction among male nurses, older nurses, nurses who were married and had children, and specialist nurses.

\section{Research hypotheses}

H1 - Nurses' job satisfaction is correlated with sociodemographic variables;

H2 - Nurses' job satisfaction is correlated with professional variables.

\section{Methodology}

The study was conducted in the district of Bragança, located in the northeast region of Portugal. The district has a total area of 6,608 $\mathrm{km}^{2}$, and a population of around 136 million inhabitants who are covered by the ULSNE. The ULSNE encompasses three hospitals and 14 health care centers. The birth rate in this region is well below the national average and the aging index is almost twice the national average. Thus, the region's health services pay special attention to age-related diseases and morbidities such as diabetes, cholesterol, and hypertension (Unidade Local de Saúde do Nordeste, 2016).

Taking into account the above-mentioned research objective and hypotheses, a descriptive, analytical, exploratory study was conducted with a quantitative approach. The population consisted of all nurses (208) who worked at the inpatient wards of the three ULSNE hospital units.

The current nursing career foresees only two categories: Nurse and Principal Nurse. However, taking into account the transition from the former career scheme, the previous categories will be used in this study (nurse, graduate nurse, specialist nurse, head nurse, supervisor nurse, regional technical nursing advisor, and technical nursing advisor (Decreto-lei 437/91, de 8 de novembro).

The data collection tool is divided into two parts. The first part refers to sociodemographic and professional data: gender, age, marital status, academic degree, professional qualifications, professional category, length of service, hospital unit (designated as A, B, C), ward, type of schedule, contractual arrangements, and remuneration. In this study, the sociodemographic and professional variables are independent variables and nurses' professional situation is the dependent variable. The second part includes the Work Satisfaction Evaluation Scale for Nurses (EAST-Enf, Escala de Avaliação da Satisfação no Trabalho para Enfermeiros; Ferreira \& Loureiro, 2012), which is composed of 25 items rated on a Likert-type scale from 1 (totally disagree) 5 (totally agree). This scale measures six dimensions: Satisfaction in the relationship with the supervisor (Satisfação no relacionamento com o chefe, SRC); Satisfaction with the benefits and rewards (Satisfação com os benefícios e recompensas, SBR); Satisfaction with the promotion (Satisfação com a promoção, SP); Satisfaction with the work context (Satisfação com o contexto de trabalho, SCT); Satisfaction with the communication (Satisfação com a comunicação, SC); Satisfaction in the relationship with the team (Satisfação no relacionamento com a equipa, SRE). The score for each dimension is calculated based on the sum of all items in each subscale. Overall, the scale total score ranges from 25 to 125 points, where a higher total score means a greater level of satisfaction. All ethical and legal procedures were met. Authorization was obtained from the authors to use the EAST-Enf. Data collection was authorized by the Board of Directors of ULSNE 
and received a favorable opinion of its Ethics Committee. Meetings with nurses were held at the wards to clarify the goals, purposes, and relevance of the study. The scale was delivered in paper format and in person. Participants were informed of the voluntary nature of their participation and asked to sign an informed consent form. They were also explained that they could withdraw from the study at any time. Anonymity, data confidentiality, and autonomy were ensured.

Of the 208 nurses who composed the population, 125 nurses participated in the study. The remaining nurses were away on vacation, on sick leave, or refused to participate in the study. One data collection tool was eliminated for not being duly filled in. Thus, the final sample was composed of 124 nurses. Data were collected between October 1 and December 31, 2015. Data were statistically analyzed using the IBM SPSS Statistics V22.0 for Windows. Inferential analysis was performed using parametric and non-parametric tests. A $p$-value $<0.05$ indicated statistical significance.

\section{Results}

\section{Sociodemographic and professional charac- teristics}

A total of 124 nurses participated in the study, most of whom $(82.3 \%)$ were women. Participants were aged between 23 and 57 years, with a mean age of 41.7 years. Most of them were married or cohabiting (74.8\%). With regard to professional qualifications, $46 \%$ had a Bache- lor's degree, $31.5 \%$ had a Specialization degree, and $9.7 \%$ had a Master's degree. In terms of professional category, $41.13 \%$ were nurses, $40.32 \%$ were graduate nurses, $16.94 \%$ were specialist nurses, and $1.61 \%$ were head nurses. Participants had 1 to 34 years of service, with a mean length of service of 17.1 years. Most respondents worked in hospital unit A (58.1\%), followed by hospital unit B (22.6\%), and hospital unit C (19.4\%). Most of them worked in an orthopedic ward (11.3\%), followed by surgery men $(10.5 \%)$, medicine $(10.5 \%)$, surgery $(9.7 \%)$, specialties $(8.9 \%)$, surgery women $(8.1 \%)$, and stroke (8.1\%). Urology (4.8\%) was the ward with the lower number of participating nurses. Most respondents worked in shifts $(82.3 \%)$ and had a public service employment contract $(59.7 \%)$. As for their remuneration, 46.8\% earned between 1000 and 1200 Euros per month, and $34.7 \%$ between 1200 and 1400 Euros per month.

\section{Nurses' satisfaction - EAST-Enf}

Table 1 shows the theoretical and observed values. The analysis of the weighted mean scores obtained in this study shows that that the surveyed nurses are very satisfied in the SRC and SRE dimensions (scores greater than 4), as well as in the SCT dimension (mean score of 3.97). Nurses are less satisfied in the SBR and SP dimensions. They were neutral in the SC (3.15) dimension and in the scale's total score (2.97). Both the total scale and each individual dimension show a low dispersion since all coefficients of variation are below 30\% (Table 1).

Table 1

Theoretical and observed values in each EAST-Enf dimension and the total scale

\begin{tabular}{lccccccccc}
\hline & \multicolumn{7}{c}{ Theoretical values } & \multicolumn{7}{c}{ Observed values } \\
\cline { 2 - 10 } & Minimum & Maximum & Mean & Minimum & Maximum & Mean & $\begin{array}{c}\text { Standard } \\
\text { error }\end{array}$ & CV (\%) & Weighted mean \\
\hline SRC & 4 & 20 & 12 & 6 & 20 & 16.68 & 3.07 & 18.4 & 4.17 \\
SBR & 5 & 25 & 15 & 5 & 17 & 9.81 & 2.58 & 26.3 & 1.96 \\
SP & 7 & 35 & 21 & 7 & 24 & 14.77 & 3.86 & 26.1 & 2.11 \\
SCT & 3 & 15 & 9 & 5 & 15 & 11.92 & 1.79 & 15.0 & 3.97 \\
SC & 4 & 20 & 12 & 4 & 19 & 12.60 & 2.58 & 20.5 & 3.15 \\
SRE & 2 & 10 & 6 & 5 & 10 & 8.40 & 1.19 & 14.2 & 4.20 \\
EAST-Enf & 25 & 125 & 75 & 43 & 99 & 74.16 & 9.02 & 12.2 & 2.97 \\
\hline
\end{tabular}

Note. $\mathrm{CV}=$ coefficient of variation; $\mathrm{SRC}=$ Satisfaction in the relationship with the supervisor; $\mathrm{SBR}=$ Satisfaction with the benefits and rewards; SP = Satisfaction with the promotion; SCT = Satisfaction with the work context; $\mathrm{SC}=$ Satisfaction with the communication; SER = Satisfaction in the relationship with the team; EAST-Enf = Work Satisfaction Evaluation Scale for Nurses. 
Cronbach's alpha values were calculated to assess the internal consistency of each dimension. Table 2 shows the Cronbach's alpha values obtained in the original study (Ferreira $\&$ Loureiro, 2012) by the authors of the scale and in this study. The SBR and SC dimensions obtained values below 0.6 , which shows a very weak and unacceptable consistency. The SBR and SC dimensions also showed unacceptable values, which were lower those found in the original study (0.49 and 0.50 , respectively). In the SCT and SP dimensions, values ranged between 0.62 and 0.68 , which indicates a low internal consistency, which is also slightly lower than the obtained in the original study $(0.68$ and 0.72 respectively). The SRC and SRE dimensions showed a good internal consistency, with alpha values of 0.82 and 0.85 , respectively, which are slightly higher than those found in the original study.

Table 2

Cronbach's alphas obtained in the original study by the authors of the scale and the authors of this study

\begin{tabular}{lcccccc}
\hline Cronbach's alpha & SRC & SBR & SP & SCT & SC & SRE \\
\hline Ferreira and Loureiro (2012) & 0.80 & 0.73 & 0.72 & 0.68 & 0.55 & 0.70 \\
Study & 0.82 & 0.49 & 0.68 & 0.62 & 0.50 & 0.85 \\
\hline
\end{tabular}

Nurses' satisfaction - EAST-Enf: sociodemographic variables

In relation to the gender variable, male nurses reported higher job satisfaction scores, but with no statistical significance.

In relation to the age variable, statistical- ly significant differences were found in the total scale and, specifically, in the SBR and SRE dimensions. Both younger nurses (aged under 30 years) and nurses older than 49 years reported higher job satisfaction scores (Table 3).

Table 3

Nurses' satisfaction according to age

\begin{tabular}{|c|c|c|c|c|c|c|c|c|c|c|}
\hline \multirow[t]{2}{*}{$\begin{array}{l}\text { Age } \\
\text { Dimension }\end{array}$} & \multicolumn{2}{|c|}{$\begin{array}{l}<30 \\
n=8\end{array}$} & \multicolumn{2}{|c|}{$\begin{array}{c}30 \text { to } 39 \\
n=46\end{array}$} & \multicolumn{2}{|c|}{$\begin{array}{c}40 \text { to } 49 \\
n=40\end{array}$} & \multicolumn{2}{|c|}{$\begin{array}{c}>49 \\
n=30\end{array}$} & \multirow[b]{2}{*}{ Statistical test } & \multirow[b]{2}{*}{$p$-value } \\
\hline & Mean & $\begin{array}{l}\text { Standard } \\
\text { deviation }\end{array}$ & Mean & $\begin{array}{l}\text { Standard } \\
\text { deviation }\end{array}$ & Mean & $\begin{array}{l}\text { Standard } \\
\text { deviation }\end{array}$ & Mean & $\begin{array}{l}\text { Standard } \\
\text { deviation }\end{array}$ & & \\
\hline SRC & 18.25 & 2.71 & 16.63 & 3.33 & 16.13 & 3.34 & 17.07 & 2.18 & $4.170^{a}$ & 0.244 \\
\hline SBR & 12.38 & 2.45 & 9.30 & 2.47 & 9.73 & 2.00 & 10.00 & 3.11 & $9.009^{\mathrm{a}}$ & $0.029^{*}$ \\
\hline SP & 18.38 & 4.47 & 14.24 & 4.09 & 14.33 & 3.45 & 15.20 & 3.47 & $6.954^{a}$ & 0.073 \\
\hline SCT & 12.50 & 2.00 & 11.83 & 2.03 & 11.70 & 1.57 & 12.20 & 1.65 & $2.259^{\mathrm{a}}$ & 0.520 \\
\hline SC & 13.38 & 2.92 & 12.65 & 2.71 & 12.18 & 2.68 & 12.87 & 2.16 & $1.947^{\mathrm{a}}$ & 0.584 \\
\hline SRE & 9.25 & 1.16 & 8.54 & 1.03 & 7.95 & 1.36 & 8.53 & 1.04 & $10.130^{\mathrm{a}}$ & $0.017^{*}$ \\
\hline EAST-Enf & 84.13 & 8.32 & 73.20 & 9.15 & 72.00 & 8.02 & 75.87 & 8.57 & $4.999^{\mathrm{b}}$ & $0.003^{* *}$ \\
\hline
\end{tabular}

Note. Age - in years. ${ }^{*}$ Significant at $5 \%{ }^{* *}$ Significant at $1 \% .{ }^{a}$ Kruskal-Wallis Test. ${ }^{\text {b }}$ Scheffe's Test.

With regard to marital status, no statistically significant differences were found; however, single and widowed nurses reported higher satisfaction scores.

With regard to the academic degree variable, a comparison was made between nurses with bachelor's degree and those with a master's degree. The $p$-values obtained every dimension were higher than $5 \%$, indicating no differences between both groups. The analysis of the total scale shows significant differences between both groups since the obtained $p$-value is lower than $5 \%$. This result shows that the level of satisfaction is different in both groups, with nurses with a lower academic degree reporting higher job satisfaction scores (Table 4). 
Table 4

Nurses' satisfaction according to the academic degree

\begin{tabular}{|c|c|c|c|c|c|c|}
\hline \multirow[t]{2}{*}{$\begin{array}{l}\text { Academic degree } \\
\text { Dimension }\end{array}$} & \multicolumn{2}{|c|}{$\begin{array}{c}\text { Bachelor's degree } \\
n=108\end{array}$} & \multicolumn{2}{|c|}{$\begin{array}{c}\text { Master's degree } \\
n=16\end{array}$} & \multirow[b]{2}{*}{ Statistical test } & \multirow[b]{2}{*}{$p$-value } \\
\hline & Mean & Standard deviation & Mean & $\begin{array}{l}\text { Standard } \\
\text { deviation }\end{array}$ & & \\
\hline SRC & 16.89 & 2.94 & 15.25 & 3.64 & $611^{\mathrm{a}}$ & 0.057 \\
\hline SBR & 9.96 & 2.56 & 8.75 & 2.54 & $646^{a}$ & 0.101 \\
\hline SP & 14.90 & 3.68 & 13.88 & 4.98 & $715.5^{\mathrm{a}}$ & 0.267 \\
\hline SCT & 12.03 & 1.61 & 11.19 & 2.69 & $794^{\mathrm{a}}$ & 0.594 \\
\hline SC & 12.67 & 2.51 & 12.13 & 3.05 & $829.5^{\mathrm{a}}$ & 0.795 \\
\hline SRE & 8.35 & 1.21 & 8.69 & 1.08 & $709^{a}$ & 0.219 \\
\hline EAST-Enf & 74.80 & 8.41 & 69.88 & 11.80 & $2.064^{\mathrm{b}}$ & $0.041^{*}$ \\
\hline
\end{tabular}

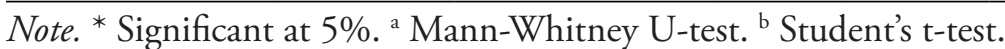

Nurses' satisfaction - EAST-Enf: professional variables

The analysis of the association between satisfaction and professional qualifications showed higher scores among specialist and postgraduate nurses; however, these differences were not significant both in relation to each dimension and the total scale, since the $p$-values were higher than 5\%.

In relation to the professional category, specialist and head nurses showed higher levels of satisfaction, both in each dimension and total scale. The obtained $p$-values were higher than $5 \%$, which shows no statistically significant differences between nurses from different categories.

Table 5 shows the results of the analysis of the association between professional satisfaction and length of service. Statistically significant differences were found in the SRC and SP dimensions and in the total scale, with $p$-values below 5\%. Nurses with less years of service reported higher levels of job satisfaction (Table 5).

Table 5

Nurses' satisfaction according to the length of service

\begin{tabular}{lcccccccc}
\hline $\begin{array}{l}\text { Length of service } \\
\text { Dimension }\end{array}$ & \multicolumn{2}{c}{$\begin{array}{c}\text { Less than } 10 \\
n=22\end{array}$} & \multicolumn{2}{c}{$\begin{array}{c}10 \\
n=50\end{array}$} & \multicolumn{2}{c}{$\begin{array}{c}20 \\
n=52\end{array}$} \\
& Mean & $\begin{array}{c}\text { Standard } \\
\text { deviation }\end{array}$ & Mean & $\begin{array}{c}\text { Standard } \\
\text { deviation }\end{array}$ & Mean & $\begin{array}{c}\text { Standard } \\
\text { deviation }\end{array}$ & Statistical test & $p$-value \\
\cline { 2 - 9 } SRC & 18.09 & 2.71 & 16.42 & 3.23 & 16.33 & 2.94 & $8.392^{\text {a }}$ & $0.015^{*}$ \\
SBR & 10.32 & 2.78 & 9.38 & 2.35 & 10.00 & 2.69 & $1.607^{\text {a }}$ & 0.448 \\
SP & 16.91 & 4.56 & 13.92 & 3.38 & 14.67 & 3.71 & $7.697^{\text {a }}$ & $0.021^{*}$ \\
SCT & 11.95 & 1.50 & 11.98 & 2.07 & 11.85 & 1.65 & $0.745^{\text {a }}$ & 0.689 \\
SC & 12.86 & 2.73 & 12.42 & 2.57 & 12.65 & 2.57 & $0.749^{\text {a }}$ & 0.687 \\
SRE & 8.45 & 1.14 & 8.50 & 1.28 & 8.27 & 1.14 & $1.489^{\mathrm{a}}$ & 0.476 \\
EAST-Enf & 78.59 & 8.63 & 72.62 & 8.45 & 73.77 & 9.27 & $6.881^{\mathrm{a}}$ & $0.032^{*}$ \\
\hline
\end{tabular}

Note.* Significant at 5\%. ${ }^{a}$ Kruskal-Wallis Test.

With regard to the hospital unit variable, institutions were coded as A, B, and C to protect their rights. Statistically significant differences were found only in the SER di- mension, in which the mean scores show higher levels of job satisfaction among nurses who worked in the hospital units $A$ and C (Table 6). 
Table 6

Nurses' satisfaction according to the hospital unit

\begin{tabular}{lcccccccc}
\hline $\begin{array}{l}\text { Hospital Unit } \\
\text { Dimension }\end{array}$ & \multicolumn{2}{c}{$\begin{array}{c}\text { A } \\
n=72\end{array}$} & \multicolumn{2}{c}{$\begin{array}{c}\text { B } \\
n=28\end{array}$} & \multicolumn{2}{c}{$\begin{array}{c}\text { C } \\
n=24\end{array}$} \\
\hline SRC & Mean & $\begin{array}{c}\text { Standard } \\
\text { deviation }\end{array}$ & Mean & $\begin{array}{c}\text { Standard } \\
\text { deviation }\end{array}$ & Mean & $\begin{array}{c}\text { Standard } \\
\text { deviation }\end{array}$ & Statistical test & $p$-value \\
\cline { 2 - 9 } SBR & 16.85 & 2.94 & 16.79 & 3.12 & 16.04 & 3.43 & $0.968^{\mathrm{a}}$ & 0.616 \\
SP & 9.89 & 2.87 & 9.43 & 1.67 & 10.00 & 2.59 & $0.565^{\mathrm{a}}$ & 0.754 \\
SCT & 14.25 & 4.08 & 15.71 & 3.40 & 15.21 & 3.59 & $3.778^{\mathrm{a}}$ & 0.151 \\
SC & 12.07 & 1.81 & 12.00 & 1.39 & 11.38 & 2.10 & $1.976^{\mathrm{a}}$ & 0.372 \\
SRE & 12.67 & 2.51 & 13.07 & 2.39 & 11.83 & 2.93 & $2.548^{\mathrm{a}}$ & 0.280 \\
EAST-Enf & 7.57 & 1.16 & 7.86 & 1.15 & 8.50 & 1.22 & $6.938^{\mathrm{a}}$ & $0.031^{*}$ \\
\hline
\end{tabular}

Note. ${ }^{*}$ Significant at 5\%. ${ }^{a}$ Kruskal-Wallis Test.

Table 7 shows the results of the comparison between the wards where nurses worked. Statistically significant differences were found in the SRC and SP dimensions, although the latter shows what is considered a borderline significance. Nurses who worked in the stroke and medicine wards reported higher levels of job satisfaction.

Table 7

Nurses' satisfaction according to the ward

\begin{tabular}{lccccccc}
\hline Ward & SRC & SBR & SP & SCT & SC & SRE & EAST-Enf \\
\hline Statistical test & $15.878^{\mathrm{a}}$ & $5.685^{\mathrm{a}}$ & $13.864^{\mathrm{a}}$ & $9.919^{\mathrm{a}}$ & $3.549^{\mathrm{a}}$ & $13.300^{\mathrm{a}}$ & $10.676^{\mathrm{a}}$ \\
$p$-value & $0.026^{*}$ & 0.577 & 0.054 & 0.193 & 0.830 & 0.065 & 0.065 \\
\hline
\end{tabular}

Note. ${ }^{*}$ Significant at 5\%. ${ }^{a}$ Kruskal-Wallis Test.

With regard to the type of schedule, shift workers reported higher levels of satisfaction, but since all $p$-values were greater than $5 \%$, no significant differences were found between nurses. With regard to the type of employment contract, although nurses with individual employment contracts reported higher scores, the difference was not significant.

Table 8 shows the results of the comparison made according to the nurses' remuneration. Statistically significant differences were found in the STC and SRE dimensions. In both cases, nurses with lower salaries (less than $€ 1,000$ ) reported higher levels of job satisfaction.

Table 8

Nurses' satisfaction according to remuneration

\begin{tabular}{lcccccccccc}
\hline $\begin{array}{l}\text { Remuneration } \\
\text { Dimension }\end{array}$ & $\begin{array}{c}\text { Less than } € 1,000 \\
n=12\end{array}$ & $\begin{array}{c}€ 1,000-€ 1,200 \\
n=58\end{array}$ & $\begin{array}{c}€ 1,200-€ 1,400 \\
n=43\end{array}$ & \multicolumn{2}{c}{$\begin{array}{c}\text { More than } € 1,400 \\
n=11\end{array}$} \\
\hline SRC & $\begin{array}{c}\text { Mean } \\
\text { Standard } \\
\text { deviation }\end{array}$ & $\begin{array}{c}\text { Mean } \\
\text { Standard } \\
\text { deviation }\end{array}$ & Mean & $\begin{array}{c}\text { Standard } \\
\text { deviation }\end{array}$ & Mean & $\begin{array}{c}\text { Standard } \\
\text { deviation }\end{array}$ & Statistical test & $p$-value \\
SBR & 17.33 & 3.14 & 16.98 & 3.20 & 16.21 & 2.85 & 16.18 & 3.22 & $4.245^{\text {a }}$ & 0.236 \\
SP & 9.67 & 3.26 & 9.97 & 2.62 & 9.77 & 2.14 & 9.27 & 3.38 & $1.001^{\text {a }}$ & 0.801 \\
SCT & 14.25 & 4.96 & 15.16 & 3.75 & 14.49 & 3.51 & 14.36 & 4.80 & $1.397^{\mathrm{a}}$ & 0.706 \\
SC & 13.25 & 1.54 & 11.78 & 1.85 & 11.44 & 1.61 & 13.09 & 1.30 & $15.883^{\mathrm{a}}$ & $0.001^{*}$ \\
SRE & 13.25 & 2.90 & 12.60 & 2.63 & 12.42 & 2.41 & 12.55 & 2.88 & $1.203^{\mathrm{a}}$ & 0.752 \\
EAST-Enf & 9.00 & 1.21 & 8.53 & 1.23 & 8.05 & 1.00 & 8.36 & 1.43 & $9.994^{\mathrm{a}}$ & $0.019^{*}$ \\
\hline
\end{tabular}

Note. Remuneration $=$ Euros. ${ }^{*}$ Significant at $5 \% .{ }^{\text {a }}$ Kruskal-Wallis Test. 


\section{Discussion}

The sample is mostly composed of women $(82.3 \%)$. According to the literature, nursing is still a predominantly female profession, which is in line with the historical background of the nursing profession. According to OE statistics (2016), on 31 December $2016,57,164$ of the 69,682 effective and active members were women. Higher job satisfaction scores were found in men, but with no statistical significance. However, Maia (2012) and Moura et al. (2016) found statistically significant gender differences, with men reporting higher levels of job satisfaction.

In relation to the age variable, statistically significant differences were found between age groups in the total scale, and specifically in the SBR and SRE dimensions. Nurses aged under 30 and over 49 years showed higher job satisfaction levels. Maia (2012) found statistically significant age differences, with older nurses showing higher levels of job satisfaction. The highest levels of job satisfaction found among younger nurses in this study may be explained by the fact that they are pleased for having found a job in the current Portuguese context.

No correlation was found between job satisfaction and marital status, which is in line with the results obtained by Maia (2012), Matos (2012), Valente (2013), and Fonseca (2014).

Statistically significant differences were found in the total scale in relation to the academic degree variable. Nurses with a lower academic degree showed higher levels of job satisfaction; in other words, graduate nurses are more satisfied than nurses with a master's degree. Maia (2012) found statistically significant differences only in the SRC dimension. Martinho (2015) found statistically significant differences in the SCT and SRE dimensions, in which graduate nurses are also significantly more satisfied than nurses with a master's degree. This may be due to the lack of recognition of their academic work.

Specialist and postgraduate nurses reported higher levels of job satisfaction, but with no statistical significance in relation to both the dimensions and the total scale. Moura et al. (2016) also found higher job satisfaction lev- els among specialist nurses, but with statistical significance.

No statistically significant differences were found between job satisfaction and professional category. However, higher scores were found among specialist and head nurses. Maia (2012) found statistically significant differences in the total scale and SP and SC dimensions. Moura et al. (2016) also found higher job satisfaction scores among specialist nurses, thus corroborating these results.

With regard to professional satisfaction and length of service, nurses with less than 10 years of service showed higher job satisfaction levels. Ferreira (2011) and Valente (2013) corroborate these results. On the other hand, Moura et al. (2016) report that the higher the length of service, the higher the nurses' job satisfaction levels.

With regard to the hospital unit where nurses worked, statistically significant differences were found only in the SRE dimension. The mean scores show that nurses from hospital units $\mathrm{A}$ and $\mathrm{C}$ have higher job satisfaction levels.

With regard to the ward where nurses worked, statistically significant differences were found in the SRC and SP dimensions, although the latter shows a borderline significance. Nurses working in the stroke and medicine wards report higher job satisfaction levels.

No significant differences were found in the job satisfaction levels of nurses with a fixed work schedule or rotating shifts. Maia (2012) found significant differences in the SP and SC dimensions and in the total scale. Martinho (2015) found significant differences in the SRC, SCT, and SC dimensions as well as that nurses with a fixed schedule showed higher job satisfaction levels.

With regard to the employment contract, nurses with an individual employment contract reported higher job satisfaction levels, although with no statistical significance. Valente (2013) also found that nurses who had an individual permanent employment contract showed higher job satisfaction levels. Nurses with a remuneration of less than 1,000 Euros reported higher levels of job satisfaction. The differences are significant in the SCT and SRE dimensions. On the opposite, according to Palha (2013), nurses with higher 
remuneration showed higher job satisfaction levels. These results may be related to the current national context, because nurses with lower salaries are younger, have fewer years of service, and are probably pleased for having an employment contract given the current professional difficulties in this area in Portugal.

This study had some limitations resulting from the lack of research carried out on this topic and using this scale in Portugal, namely in terms of literature review and the subsequent discussion of results. Despite these limitations, this study may contribute to a better understanding of the assessment of nurses' job satisfaction.

\section{Conclusion}

Every health organization should measure its professionals' job satisfaction levels because it is a key aspect to assess their performance, as well as the quality of the institutions and care delivery.

The obtained results demonstrate that nurses' job satisfaction is associated with demographic (age and academic degree) and professional factors (length of service, hospital unit, ward, and remuneration).

The assessment of this indicator is of the utmost importance for management and decision-making, given the direct association between job satisfaction and quality of care delivery.

Longitudinal studies should be developed to systematically monitor nurses' job satisfaction levels throughout their professional career, seeking to identify the factors and variables that promote and influence these professionals' satisfaction. Future studies should focus on other variables, internal or external to nurses' performance, with a view to eliminating weaknesses and increasing job satisfaction levels.

\section{References}

Cañon Buitrago, S. C., \& Galeano Martinez, G. (2011). Factores laborales psicosociales y calidad de vida laboral de los trabajadores de la salud de ASSBASA-
LUD E.S.E. Manizales (Colombia). Archivos de Medicina, 11(2), 114-126. Retrieved from http:// www.redalyc.org/articulo.oa?id=273821489004

Conselho Internacional de Enfermeiros. (2007). Ambientes favoráveis à prática: Condiçóes no trabalho = Cuidados de qualidade. Lisboa, Portugal: Ordem dos Enfermeiros.

Decreto-Lei no 437/1991 de 8 de novembro. Diário da República no 257/1991 - I Série. Ministério da Saúde. Lisboa, Portugal.

Dinis, L. I., \& Fronteira, I. (2015). A influência da rotação no trabalho na satisfaçáo profissional dos enfermeiros num serviço de cirurgia. Revista de Enfermagem Referência, 4(5), 17-26. http://dx.doi. org/10.12707/RIV14008

Direção-Geral da Saúde. (2013). Plano Nacional de Saúde 2012-2016. Lisboa, Portugal: Autor. Retrieved from http://1nj5ms2lli5hdggbe $3 \mathrm{~mm} 7 \mathrm{~ms} 5$. wpengine.netdnacdn.com/files/2012/02/0024_-Qualidade_em_Saúde_2013-01-17_.pdf

Ferreira, M., \& Loureiro, L. (2012). EAST-Enf: Uma escala de avaliação da satisfação no trabalho para enfermeiros. Revista de Investigação em Enfermagem, 2(1), 7-13.

Ferreira, V. L. (2011). A satisfação profissional dos enfermeiros em cuidados de saúde primários no distrito de Braga (Unpublished Master's Dissertation). Universidade do Porto, Faculdade de Economia, Porto. Retrieved from https://repositorio-aberto. up.pt/bitstream/10216/56197/2/DissertaoMestrado Vera.pdf

Fonseca, R. M. (2014). Satisfação profissional nas USF da ARS Centro: Fatores intrinsecos e extrinsecos do trabalho (Unpublished Master's Dissertation). Faculdade de Economia da Universidade de Coimbra, Coimbra. Retrieved from http://hdl.handle. net/10316/27359

Frade, J. T. (2010). Análise estatística do inquérito nacional de saúde e determinantes da qualidade de vida dos portugueses (Unpublished Master's Dissertation). Faculdade de Economia da Universidade de Coimbra, Coimbra Retrieved from http://hdl.handle. net/10316/14365

João, A. L., Alves, C. P., Silva, C., Diogo, F., \& Ferreira, N. D. (2017). Validação de uma escala de satisfação dos enfermeiros com o trabalho para a população portuguesa. Revista de Enfermagem Referência, 4(12), 117130. doi.org/10.12707/RIV16066

Lei no 27/2002 de 8 de novembro. Diário da República $n^{\circ}$ 258/2002. Série I-A. Ministério da Saúde. Lisboa, Portugal.

Maia, N. (2012). Satisfação em enfermagem: Comparação entre sector público e privado (Unpublished Mas- 
ter's Dissertation). Universidade de Aveiro, Aveiro. Retrieved from http://hdl.handle.net/10773/8792

Martinho, J. M. (2015). Satisfação profissional dos enfermeiros especialistas em enfermagem de reabilitação (Unpublished Master's Dissertation). Instituto Politécnico de Viseu, Viseu. Retrieved from http:// hdl.handle.net/10400.19/3229

Matos, V. M. (2012). Monitorização da satisfação profissional num agrupamento de centros de saúde da região do centro (Unpublished Master's Dissertation). Faculdade de Economia da Universidade de Coimbra, Coimbra. Retrieved from http://hdl.handle. net/10316/21497

Moura, S., Brás, M., Anes, E., \& Ferreira, C. (2016). Satisfação no trabalho em profissionais de enfermagem. In III Encontro de Jovens Investigadores do Instituto Politécnico de Bragança: Livro de Resumos, 11-13 Novembro 2015 (p. 35). Bragança, Portugal: Instituto Politécnico de Bragança. Retrieved from https://bibliotecadigital.ipb.pt/ bitstream/10198/10366/6/2015\%20EJI\%20
Livro\%20de\%20Resumos.pdf

Ordem dos Enfermeiros. (2006). Investigação: Tomada de posição. Lisboa, Portugal: Autor.

Ordem dos Enfermeiros. (2016). OEDATA em 31-122016, membros activos. Retrieved from http://www. ordemenfermeiros.pt/Documents/2016_DadosEstatisticos_00_Nacionais.pdf

Palha, M. F. (2013). Satisfação profissional dos enfermeiros em unidades de cuidados continuados integrados (Unpublished Master's Dissertation). Instituto Politécnico do Porto, Portugal. Retrieved from http://hdl.handle.net/10400.22/8952

Unidade Local de Saúde do Nordeste. (2016). Boletim Informativo da ULSNE de Fevereiro de 2016. ULSNE. Retrieved from http://www.ulsne.min-saude. pt/comunicacao/informacao/

Valente, J. P. (2013). Satisfação profissional dos enfermeiros de um hospital da região do centro (Unpublished Master's Dissertation). Instituto Politécnico de Viseu, Portugal. Retrieved from http://hdl.handle.net/10400.19/2059 